\title{
Effect of Fertility Levels and Cow Urine Foliar Spray on Growth and Yield of Wheat
}

\author{
R. Sadhukhan ${ }^{1 *}$, J.S. Bohra ${ }^{2}$ and Sourav Choudhury ${ }^{3}$ \\ ${ }^{1}$ Division of Agronomy, IARI, New Delhi-110012, India \\ ${ }^{2}$ Department of Agronomy, Banaras Hindu University, UP, India \\ Division of Soil Science and Agricultural Chemistry, Banaras Hindu University, UP, India \\ *Corresponding author
}

\section{A B S T R A C T}

\section{Keywords}

Cow urine spray,

Fertility levels,

Growth and yield

Article Info

Accepted:

10 February 2018

Available Online:

10 March 2018

A field experiment was conducted in the rabi season on Integrated Farming System at BHU, Varanasi to evaluate the effect of different level of fertility and cow urine foliar spray on growth, yield and yield attributes of wheat (Var-HUW 234). The grain yield and straw yield of wheat varied significantly under varying levels of fertility and cow urine foliar sprays. The experiment was conducted under the split plot design with three replications. However, the response of fertility levels $\left(\mathrm{RDF}=120-60-60-25 \mathrm{~kg} \mathrm{ha}^{-1}\right.$ of NPKZn levels) to the improvement of grain and straw yield was positively correlated and the same was also true in case of grain and straw yield increment with the spray of cow urine. The Cow urine foliar sprays (four) were done at 20 days interval from 30 DAS to 90 DAS to study the effect on growth and yield of wheat. It was reported that application of $80 \%$ and $100 \%$ RDF, respectively recorded $10.37 \%$ and $20.46 \%$ higher grain yield over $60 \%$ RDF. Moreover, application of $50 \%$, $75 \%$ and $100 \%$ cow urine spray recorded $2.69 \%, 18.01 \%$ and $27.21 \%$ higher grain yield, respectively over control.

\section{Introduction}

Farming system (FS) has been generally mentioned everywhere as a combined effort of crop and livestocks (cattle). Wheat is one of the most important cereal crop in the world. In India, wheat is the second most important staple cultivated food after rice and consumed by nearly $65 \%$ of the Indian population (Mishra et al., 2005) and rank first in dietary shares in northern India represented by Gangetic plains (Joshi et al., 2007). Presently, wheat accounts for 96.64 MT (2016-17). But, the growth in production has led to India now being the world's second largest producer of wheat. However, the increasing imbalanced and indiscriminate use of chemical fertilizers leads to deterioration of soil health and fertility. So, integrated nutrient management (INM) is the most appropriate and adoptable practice in which both organic and inorganic sources of nutrients is included, with an objective to increase crop production without deterioration of soil fertility. The concept of organic farming has been gaining momentum with the use of different manures with the liquid organic manures can help to maintain optimum crop yield by maintaining the fertility status (Arun Kumar et al., 2014). The integrated use of inorganic fertilizers with the 
liquid organic manures (cow urine) can help to maintain optimum crop yield by maintaining fertility status of the soil. Cow urine contains 95\% water, $2.5 \%$ urea, and $2.5 \%$ minerals, salts, hormones and enzymes. It also contains essential minerals like iron, calcium, phosphorus, carbonic acid, potash, nitrogen, ammonia, manganese, sulphur, phosphates and potassium, urea, uric acid, amino acids, enzymes, cytokinin, lactose etc. (Bhadauria, 2002). Research shows that only $20 \%$ of nitrogenous materials consumed by cattle are absorbed and $80 \%$ is excreted in urine and dung. The beneficial effect of cow urine application has been reported on several crops such as on mustard (Gupta, 2005, Meena et al., 2013 and Pradhan et al., 2016), Maize (Devakumar et al., 2014), and Sweet corn (Pande et al., 2015), and on vegetables such as on Watermelon (Burubhai and Eribo, 2012), Chilli (Keduka et al., 2014) and Lablab bean (Maheshari et al., 2017). With these facts, the present study entitled the effect of fertility levels and cow urine foliar spray on growth, yield and yield attributes of wheat.

\section{Materials and Methods}

A study was conducted at the Agricultural Research Farm, Institute of Agricultural Sciences, Banaras Hindu University, Varanasi during rabi seasons of 2015-16 on the wheat variety named HUW-234. The experiment was laid out in split plot design with three main plots and four sub plots and that was replicated thrice. The main plot factors are $\mathrm{F}_{1^{-}}$ $60 \%$ of recommended dose of fertilizer (12060-60-25 kg ha ${ }^{-1}$ of $\mathrm{N}, \mathrm{P}_{2} \mathrm{O}_{5}, \mathrm{~K}_{2} \mathrm{O}$ and $\mathrm{ZnSO}_{4}$ ), $\mathrm{F}_{2^{-}} \quad 80 \% \quad \mathrm{RDF}$ and $\mathrm{F}_{3^{-}} \quad 100 \%$ RDF, respectively. The subplots were $\mathrm{U}_{0^{-}}$water spray, $\mathrm{U}_{1}-50 \%$ cow urine spray, $\mathrm{U}_{2}-75 \%$ cow urine spray and $\mathrm{U}_{3}-100 \%$ cow urine spray. The half dose of $\mathrm{N}$ and full doses of $\mathrm{P}_{2} \mathrm{O}_{5}$ and $\mathrm{K}_{2} \mathrm{O}$ was applied as basal dose and remaining one-fourth of $\mathrm{N}$ was applied as first top dressing and second top dressing at 40 DAS and 60 DAS respectively. Four foliar sprays of cow urine at 30, 50, 70 and 90 DAS were applied to observe the effect of cow urine on growth, yield and yield attributes of wheat. The seed sowing was done with the spacing of $22.5 \mathrm{~cm} \times$ not maintained. The observations were recorded on the various aspects pertaining to growth parameters viz. plant height, LAI and yield attributes such as number of ear $\mathrm{m}^{-2}$, number of grain ear $^{-1}$, Test weight $(\mathrm{g})$, Grain yield and straw yield etc.

\section{Results and Discussion}

\section{Growth}

Plant height, LAI of wheat plant varied markedly due to different soil fertility levels and cow urine as foliar sprays in different concentrations. Taller plants and higher tiller numbers at all the stages of plant growth were found in highest fertility levels and maximum cow urine concentration as foliar sprays. In 2015 data, the fertilizer applied at 100\% RDF produced significantly taller plants than $60 \%$ $\mathrm{RDF}$ at all the growth stages. It was evident that wheat plants supplied with adequate amount of major nutrients (100\% RDF) produced more leaves and prolific roots for supply of nutrients and water and hence brought about greater accumulation of photosynthates, yielding more height, LAI (70 DAS) in all the growth stages (Table 1).

The growth attributing characters progressed presumably because of better supply of nitrogen and other major, secondary and micro-nutrient at higher rate of urine application. The different enzymes and hormones present in cow urine are also lead to better growth of plant (Vahanka et al., 2010).

\section{Yield attributes}

Yield attributes such as ears $\mathrm{m}^{-2}$, grains ear ${ }^{-1}$, 1000-grain weight, and improved remarkably due to increase fertility levels from 60 to $100 \%$ RDF in the experimental year, 2015-16. 
Table.1 Effect of fertility levels and cow urine spray (Four foliar spray) on growth of wheat

\begin{tabular}{|l|c|c|c|c|}
\hline \multicolumn{5}{|c}{ Growth parameters of Wheat } \\
\hline Treatments & \multicolumn{2}{|c|}{ Plant height $(\mathrm{cm})$} & Leaf Area Index \\
\hline Fertility Levels & 40 DAS & 70 DAS & At Harvest & At 70 DAS \\
\hline $\mathbf{6 0 \%}$ RDF & 32.31 & 93.73 & 92.02 & 3.37 \\
\hline $\mathbf{8 0 \%}$ RDF & 33.00 & 97.19 & 93.52 & 3.49 \\
\hline $\mathbf{1 0 0 \%}$ RDF & 34.15 & 98.19 & 99.08 & 3.76 \\
\hline SEm \pm & 0.34 & 0.85 & 0.88 & 0.03 \\
\hline CD at 5\% & $\mathbf{1 . 3 3}$ & $\mathbf{3 . 3 3}$ & $\mathbf{3 . 4 5}$ & $\mathbf{0 . 1 3}$ \\
\hline Cow Urine spray & & & & \\
\hline Control & 32.806 & 94.81 & 92.94 & 3.32 \\
\hline $\mathbf{5 0 \%}$ CU & 33.056 & 95.22 & 93.53 & 3.49 \\
\hline $\mathbf{7 5 \%}$ CU & 33.389 & 96.08 & 94.83 & 3.56 \\
\hline $\mathbf{1 0 0 \%}$ CU & 33.361 & 99.36 & 98.19 & 3.80 \\
\hline SEm \pm & 0.606 & 1.12 & 1.26 & 0.04 \\
\hline CD at 5\% & NS & $\mathbf{3 . 3 4}$ & $\mathbf{3 . 7 3}$ & $\mathbf{0 . 1 1}$ \\
\hline
\end{tabular}

Table.2 Effect of fertility levels and cow urine spray (Four foliar spray) on yield attributes of wheat

\begin{tabular}{|c|c|c|c|}
\hline \multirow{3}{*}{\begin{tabular}{|l|} 
Treatments \\
Fertility Levels
\end{tabular}} & \multirow{3}{*}{$\begin{array}{l}\text { Ear numbers per } \\
\text { square meter }\end{array}$} & $\begin{array}{l}\text { Yield attributes of } \\
\text { Wheat }\end{array}$ & \multirow[b]{2}{*}{ Test weight (g) } \\
\hline & & $\begin{array}{l}\text { Grain numbers per } \\
\text { ear }\end{array}$ & \\
\hline & & & \\
\hline $60 \% \mathrm{RDF}$ & 290.75 & 35.28 & 37.32 \\
\hline $80 \%$ RDF & 296.42 & 37.52 & 37.73 \\
\hline $100 \%$ RDF & 314.75 & 39.51 & 40.28 \\
\hline SEm \pm & 3.97 & 0.72 & 0.49 \\
\hline CD at $5 \%$ & 15.61 & 2.84 & 1.94 \\
\hline \multicolumn{4}{|l|}{ Cow Urine spray } \\
\hline Control & 284.33 & 92.9 & 37.48 \\
\hline $50 \% \mathrm{CU}$ & 297.11 & 93.5 & 38.04 \\
\hline $75 \% \mathrm{CU}$ & 305.44 & 94.8 & 38.71 \\
\hline $100 \% \mathrm{CU}$ & 315.67 & 98.2 & 39.53 \\
\hline SEm \pm & 5.61 & 1.26 & 0.48 \\
\hline CD at $5 \%$ & 16.67 & 3.73 & 1.42 \\
\hline
\end{tabular}


Table.3 Effect of fertility levels and cow urine spray (Four foliar spray) on yield of wheat

\begin{tabular}{|l|c|c|c|}
\hline Treatments & $\begin{array}{l}\text { Yrain Yield } \\
(\mathrm{q} / \mathrm{ha})\end{array}$ & $\begin{array}{l}\text { Straw Yield } \\
(\mathrm{q} / \mathrm{ha})\end{array}$ & Harvest Index (\%) \\
\hline Fertility Levels & & & \\
\hline $\mathbf{6 0 \%}$ RDF & 27.46 & 40.48 & 40.41 \\
\hline $\mathbf{8 0 \%}$ RDF & 30.31 & 41.50 & 42.20 \\
\hline $\mathbf{1 0 0 \%}$ RDF & 33.08 & 45.16 & 42.28 \\
\hline SEm & 1.05 & 0.64 & 0.80 \\
\hline CD at 5\% & $\mathbf{4 . 1 4}$ & $\mathbf{2 . 5 3}$ & $\mathbf{2 . 4 0}$ \\
\hline Cow Urine spray & & & 40.01 \\
\hline Control & 27.04 & 40.54 & 40.08 \\
\hline $\mathbf{5 0 \%}$ CU & 27.77 & 41.50 & 42.55 \\
\hline $\mathbf{7 5 \%}$ CU & 31.93 & 43.11 & 43.67 \\
\hline $\mathbf{1 0 0 \%}$ CU & 34.40 & 44.37 & 0.90 \\
\hline SEm \pm & 1.19 & 0.86 & $\mathbf{2 . 7 0}$ \\
\hline CD at 5\% & $\mathbf{3 . 5 4}$ & $\mathbf{2 . 5 6}$ & \\
\hline
\end{tabular}

Dig: $100 \%$ fertility levels and $100 \%$ cow urine treated experimental plot

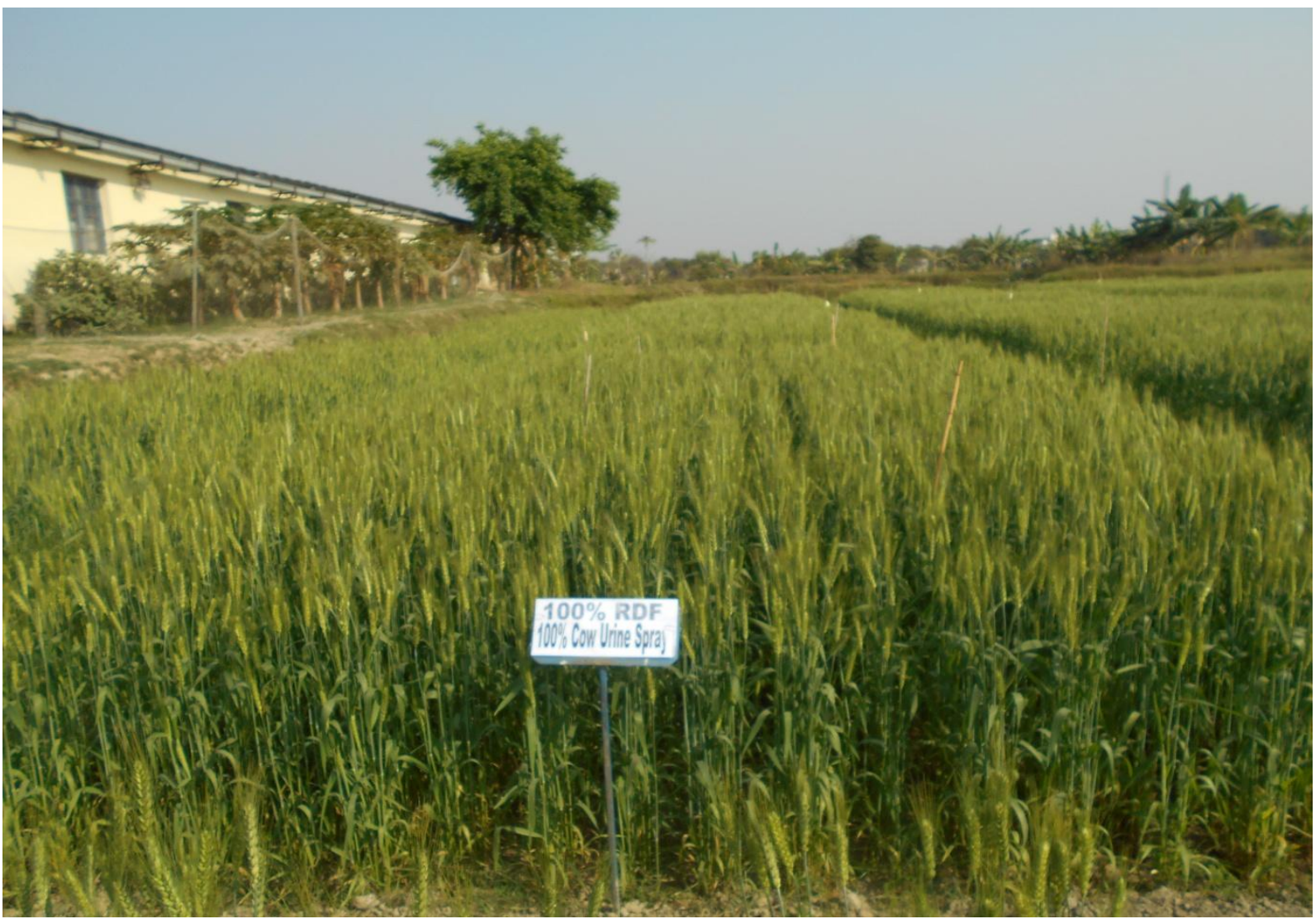


The highest values of ears $\mathrm{m}^{-2}$, grains ear ${ }^{-1}$, 1000-grain weight, and in 2015 were recorded with $100 \%$ RDF. So, $100 \%$ RDF was distinctly superior to other fertility levels. The increased grain yield at higher fertility level may be attributed to the increased vegetative growth and better availability of nutrients during growth period, more synthesis of carbohydrates and their translocation (Muthuswamy et al., 1990 and Minhas and Sood, 1994, Mondal et al., (2013), Singh et al., (2014) and Srivastava et al., (2014). Consequently, the highest values of ears $\mathrm{m}^{-2}$, grains ear ${ }^{-1}$, 1000-grain weight, and during 2015 were recorded with $100 \%$ foliar spray of cow urine (Table 2).

\section{Yield}

Grain yield in the year of experimentation (2015 - 2016) showed significant variation due to $100 \%$ fertility levels and $100 \%$ cow urine as foliar spray. It was reported that application of $80 \%$ and $100 \%$ RDF, respectively recorded $10.37 \%$ and $20.46 \%$ higher grain yield over $60 \%$ RDF. Moreover, application of $50 \%, 75 \%$ and $100 \%$ cow urine spray recorded $2.69 \%, 18.01 \%$ and $27.21 \%$ higher grain yield, respectively over control (Table 3).

The highest grain yield was noticed at $100 \%$ $\mathrm{RDF}$ and also at $100 \%$ foliar spray of cow urine. It was noticed that grain yield of rice was improved with increasing concentration of cow urine from control to $100 \%$ in the year (2015 - 2016). Straw yield also increased with each increment of fertility level upto highest level. Application of 50\%, $75 \%$ and $100 \%$ cow urine recorded $2.36 \%, 6.33 \%$ and $9.44 \%$ higher straw yield, respectively than control. It is apparent from the data that the fertility levels able to influence the harvest index to the level of significance in the year (2015 2016). Similarly, linear trend was noticed in harvest index with different concentrations of cow urine application as foliar spray.
On the basis of the result obtained from the experiment, it can be concluded that $100 \%$ RDF and four sprayings of cow urine should be rice to be proved most effective in increasing growth and yield of wheat under the integrated farming system.

\section{Acknowledgement}

I am very much thankful to our Banaras Hindu University for providing me research resources and my chairperson Professor J.S. Bohra for guiding me during my research session of 2015-17.

\section{References}

Abbad, A., Lloveras, J. and Michlena. A. 2004. Nitrogen fertilization and foliar urea effects on Durum wheat yield and quality and on residual soil nitrate in irrigated Mediterranean conditions. Field Crops Research 87: 257-269.

Ali, A., Ahmad, A., Syed, W.H., Khaliq, T., Asif, M., Aziz, M. and Mubeen, M. 2011. Effects of nitrogen on growth and yield Components of wheat. (Report). Science International (Lahore), 23(4): 331-332.

Ali, M.S., Hossain, M.S., Sobahan, M.A., Alam, M.A. and Bhuiyan, M.S.H. (2006). Effect of organic manures and nitrogen levels on plant height and number of tillers hill $^{-1}$ of aman rice. Journal of Sub Tropical Agricultural Research and Development, 5(3): 291296.

Bhadauria, H. (2002). Cow urine-a magical therapy. International Journal of Cow Science, 1: 32-36.

Burubai, W., and Eribo, M. (2012). Influence of incubation periods and dosage on the bioefficacy of cow urine against melon aphids (Aphis gossypii) and pickleworms (Diaphania hyalinata) in watermelon cultivation. Research Journal of Applied Sciences, 
Engineering and Technology, 4(4), 269272.

Devakumar, N., Shubha, S., Rao, G.G.E. and Imran Khan (2014). Studies on Soil fertility, Cow urine and Panchagavya levels on Growth and Yield of Maize. $4^{\text {th }}$ ISOFAR Scientific congress. Building Organic Bridges, 4: 627-629.

Guo, Z.H., Li, H., Zhang, Y.Z., Huang, J and Huang, C.Y. (2002). Effects of phosphorous levels on hybrid rice growth and characteristics of phosphorus transportation. Chinese Journal of Rice Science, 16(2): 151156.

Gupta, M. P. (2005). Efficacy of neem in combination with cow urine against mustard aphid and its effect on coccinellid predators. Natural Product Radiance, 4(2): 90-92.

Hemantaranjan, A. (1994). Physiological Significance of Aluminium, Vanadium and Zinc on the Sensitivity on NitrogenFixation, Growth and Yield of Phaseolus vulgaris L. In New Perspectives in the Research of Hardly Known Trace Elements and in Element Interaction: Proceedings of the 6 . International Symposium, Budapest, Hungary, July 1994 (p. 45). University of Horticulture and Food Science.

Kumar, A., Meena, R.N., Yadav. L., and Gilotia Y.K. (2014). Effect of Organic and Inorganic sources of nutrient on yield, yield attributes and nutrient uptake of rice cv. PRH-10. The Bioscan, 9(2):595-597.

Maheswari, V.N., Kaleena, P.K., Srikumaran, M.P., Rekha, G.S. and Elumalai, D. (2017). Influence of vermiwash and panchagavya on lablab beans under pot experimental conditions. International Journal of Advances Research. on Biological. Sciences, 4(2), 20.

Meena, H., Singh, S. P. and Nagar, R. (2013). Evaluation of microbial agents and bioproducts for the management of mustard aphid, Lipaphis erysimi (Kalt). The Bioscan, 8(3):747-750.

Meena, R.K., Neupane, M.P. and Singh, S.P. (2014). Effect of phosphorus levels and bio-organic sources on growth and yield of rice (Oryza sativa L.). Indian Journal of Nutrition, 1(1): 105.

Pande, S., Naik, M.R., and Naidu, S.M. (2015). Effect of Different Sources of Organic Manuries on Sweet Corn (Zea mays Saccharata). Environment and Ecology, 33(2A), 810-813.

Pradhan, S., Bohra, J.S., Bahadur, S., Singh, M.K. and Ram, L. (2016). Effect of fertility levels and cow urine application on the growth and uptake of nutrients of Indian mustard [Brassica juncea (L.) Czern. \& Coss]. Research on Crops, 17(4):77-84.

Quyen, N.V. and Sharma, S.N. (2003). Relative effect of organic and conventional farming on growth grain quality of scented rice and soil fertility. Archives of Agronomy and Soil Sciences, 49: 623-629.

Singh, M.K., Singh, R.P. and Rai, S. (2014). Effect of Nitrogen Levels and Cow Urine on Soil N Status, Growth and Yield on Paddy (Oryza sativa L.). Environment and Ecology, 32(4): 12771281.

\section{How to cite this article:}

Sadhukhan, R., J.S. Bohra and Sourav Choudhury. 2018. Effect of Fertility Levels and Cow Urine Foliar Spray on Growth and Yield of Wheat. Int.J.Curr.Microbiol.App.Sci. 7(03): 907912. doi: https://doi.org/10.20546/ijcmas.2018.703.106 